\title{
Acknowledgment to Reviewers of European Burn Journal in 2021
}

\section{EBJ Editorial Office}

Citation: EBJ Editorial Office.

Acknowledgment to Reviewers of European Burn Journal in 2021. Eur. Burn J. 2022, 3, 56. https://doi.org/ 10.3390/ebj3010007

Published: 28 January 2022

Publisher's Note: MDPI stays neutral with regard to jurisdictional claims in published maps and institutional affiliations.

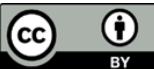

Copyright: (c) 2022 by the authors. Licensee MDPI, Basel, Switzerland. This article is an open access article distributed under the terms and conditions of the Creative Commons Attribution (CC BY) license (http://creativecommons.org/licenses/by/4.0/).

MDPI AG, St. Alban-Anlage 66, 4052 Basel, Switzerland

Rigorous peer-reviews are the basis of high-quality academic publishing. Thanks to the great efforts of our reviewers, European Burn Journal (EBJ) was able to maintain its standards for the high quality of its published papers. Thanks to the contribution of our reviewers, in 2021, the median time to first decision was 23 days and the median time to publication was 62 days. The editors would like to extend their gratitude and recognition to the following reviewers for their precious time and dedication, regardless of whether the papers they reviewed were finally published:

Alexandrino Júnior, Francisco

Andrews, Christine J.

Caffre, Julie

Cancio, Leopoldo C.

Caviggioli, Fabio

Chhibber, Tanya

Chung, Kevin K.

Depetris, Nadia

Fochtmann-Frana, Alexandra

Fuchs, Paul

Griffin, Bronwyn

Grillo, Sara

Haik, Josef

Harats, Moti

Hazeldine, Jon

Herrán-Monge, Rubén

Hofmann, Elisabeth

Huss, Fredrik

Infante, Victor

Jeffery, Steve

Kamolz, Lars-Peter

Konop, Marek

Kornhaber, Rachel

Krezdorn, Nicco

Kym, Dohern

Lavrentieva, Athina

Li-Tsang, Cecilia
Mackie, David

Meirte, Jill

Moakes, Richard

Ogawa, Rei

Park, Caroline

Pham, Tam N.

Pittermann, Anna

Pompermaier, Laura

Pruskowski, Kaitlin A.

Rennekampff, Hans-Oliver

Rizzo, Julie

Ross, Evan

Russo, Teresa

Ryan, Colleen M.

Sánchez-Sanchez, Manuel

Schiestl, Clemens

Schröttner, Percy

Shah, Mamta

Shepherd, Laura

Singer, Yvonne

Sirvent, Ramon

Stella, Maurizio

Stocco, Chiara

Van Loey, Nancy

Vuola, Jyrki

Wilson, Yvonne

Zicha, Daniel 